Per Pippin Aspaas \& László Kontler, "Before and after 1773: Central European Jesuits, the Politics of Language and Discourses of Identity in the Late Eighteenth Century Habsburg Monarchy", final manuscript version ("postprint") of book chapter in Gábor Almási \& Lav Subarić (eds.), Latin at the Crossroads of Identity: The Evolution of Linguistic Nationalism in the Kingdom of Hungary (Leiden: Brill, 2015), pp. 95118. (=Brill's book series Central and Eastern Europe: Regional Perspectives in Global Context, vol. 5)

Per Pippin Aspaas (University of Troms $\varnothing$ - The Arctic University of Norway) / László Kontler (Central European University, Budapest)

\title{
Before and after 1773: Central European Jesuits, the politics of language and discourses of identity in the late eighteenth century Habsburg Monarchy
}

The eighteenth century is widely regarded as having inaugurated the advent of multi-lingual modernity in European culture. ${ }^{1}$ Even learned communication within the republic of letters seems to have been gradually but decisively shifting towards the use of modernised vernaculars. Yet, amidst the competition with French as an emerging international lingua franca, as well as with local rivals, Latin demonstrated a strong resilience. Latin was not only the sacred language of a Church (ideally) encompassing the entirety of humanity, it was also seen by many as a prerequisite for the unity and universality of the transnational respublica litteraria. ${ }^{2}$ Jesuit scholars were foremost among those who continued to champion the cause of Latin in learned communication. The suppression of the Society of Jesus, which culminated in the 1773 bull of Pope Clemens XIV, marks therefore a watershed in the contest of Latin with European vernacular languages for the control of learned discourse.

Until this point, the Habsburg Monarchy had been recognised as a stronghold of Jesuit learning - and of the Latin language. It was not merely a question of the religious policies of the House of Habsburg, which tended to promote conservative Catholicism and, almost by consequence, Latin; other factors were important as well. In addition to religion, the cultural, political and ethnic diversity of the Habsburg lands lay at the heart of the language question, or rather language questions, of the time. Latin not only had a part to play when universalist ideals were at stake. Paradoxically, the cultivation of the ancient tongue could also be turned to entrenching the identities of "subaltern" groups in the empire. Its status as an official language of the Kingdom of Hungary illustrates this. When Joseph II attempted to impose German as the official language of entire Hungary with his 1784 German language edict, he met with fierce opposition. This opposition ran essentially along two lines: either Latin was

\footnotetext{
${ }^{1}$ F. Oz-Salzberger, "The Enlightenment in Translation: Regional, Cosmopolitan and National Aspects," European Review of History / Revue européenne d'histoire, 13, no. 3 (2006), 385-410, with references. ${ }^{2}$ E.g. R. Chartier and P. Corsi, eds., Sciences et langues en Europe (Paris 1996); F. Wacquet, Latin or the Empire of a Sign: From the Sixteenth to the Twentieth Centuries (London 2001); P. Burke, Languages and Communities in Early Modern Europe (Cambridge 2004). For a brief discussion, see P. P. Aspaas, "The use of Latin and the European Republic of Letters: Change and continuity in the seventeenth and eighteenth centuries," Nordlit 33 (2014), 281-295 (also available at http://septentrio.uit.no/index.php/nordlit/article/view/3169/3038).
} 
Per Pippin Aspaas \& László Kontler, "Before and after 1773: Central European Jesuits, the Politics of Language and Discourses of Identity in the Late Eighteenth Century Habsburg Monarchy", final manuscript version ("postprint") of book chapter in Gábor Almási \& Lav Subarić (eds.), Latin at the Crossroads of Identity: The Evolution of Linguistic Nationalism in the Kingdom of Hungary (Leiden: Brill, 2015), pp. 95118. (=Brill's book series Central and Eastern Europe: Regional Perspectives in Global Context, vol. 5)

to be retained, or Hungarian (not German) was to be allowed alongside Latin. ${ }^{3}$ Soon, during the 50 years when the use of Hungarian in public affairs was promoted vigorously and finally became enacted in 1844, the Croats would resist the spread of Magyar in exactly the same way: while Latin for the Hungarians during the 1780s had served as a bulwark against Germanisation, it was later evoked to protect the Croats against Magyarisation. ${ }^{4}$ Earlier in the eighteenth century, Orthodox Serbs had included Latin in the curriculum of their religious schools, partly as a measure to avoid too much restriction from Habsburg censorship regarding the substance of their teachings. ${ }^{5}$ Finally, in this ethnically and linguistically diverse country, Latin served as an identity marker in a more comprehensive sense. More than an ordinary lingua franca, Latin can be considered a "second mother tongue" for the population of Hungary during the early modern period. ${ }^{6}$ Those who were not necessarily Magyar (Hungarian) by descent and language could still be identified as Hungarus, i.e. members of the Hungarica natio. This concept emerged from the mid-seventeenth century onwards, and by the later eighteenth century it had come to denote a cultural and civilpolitical community bound together by allegiance to the values of national tolerance and neutrality, and to the cultural, administrative and legal traditions of the composite, multiethnic Kingdom of Hungary. ${ }^{7}$ Latin was the language of these traditions, and thus a preeminent factor in cementing the unity and integrity of the country.

${ }^{3}$ É. H. Balázs, Hungary and the Habsburgs, 1765-1800: An Experiment in Enlightened Absolutism (Budapest 1997), 205-211.

${ }^{4}$ H. Jurčić, "Das ungarisch-kroatische Verhältnis im Spiegel des Sprachenstreites 1790-1848,” UngarnJahrbuch 3 (1971), 68-87.

${ }^{5}$ See the article by Nenad Ristović in the present volume. Also see his "Acculturation versus Assimilation. The role of the Orthodox Church in the Organization of Western Modern-Age Classical Education among the Serbs in the Habsburg Monarchy," in Encounters in Europe's Southeast: The Habsburg Empire and the Orthodox World in the Eighteenth and Nineteenth Centuries, ed. by H. Heppner and E. Posch (Bochum 2012), 191-204. ${ }^{6}$ I. Gy. Tóth, Literacy and Written Culture in Early Modern Central Europe (Budapest 2000), 130-145; id., "Les analphabètes et les almanachs en Hongrie au XVIIIe siècle," in Les lectures du peuple en Europe et dans les Amériques du XVIIe aи XXe siècle, ed. by H.-J. Lüsebrink, Y.-G. Mix, J.-Y. Mollier and P. Sorel (Brussels 2003), 127-133.

${ }^{7}$ Some scholars have attributed the rise of the concept to the philosophy of history worked out by Hungarian Jesuits and, more generally, to the "national Baroque"; others to the patriotism of the Slovak and German Lutheran professionals; still others stress that from the mid-eighteenth century the Enlightenment notion of humanity (Humanität / Menschenliebe) was crucial to it. See Gy. Szekfü, Magyar történet [Hungarian history] (Budapest 1935), 4:378-379; A. Tarnai, Extra Hungariam non est vita ... (Egy szállóige történetéhez) [Extra Hungariam non est vita ... On the history of an adage] (Budapest 1969), 99-100; M. Csáky, "Die HungarusKonzeption," in Ungarn und Österreich unter Maria Theresia und Joseph II., ed. by A. M. Drabek, R. G. Plaschka and A. Wandruszka (Vienna 1982), 71-89; I. Fried, “A hungarus-tudat kérdőjelei” [Question marks of the Hungarus consciousness], in A közép-európai szöveguniverzum (Budapest 2002), 47-68; A. Miskolczy, “A 
Per Pippin Aspaas \& László Kontler, "Before and after 1773: Central European Jesuits, the Politics of Language and Discourses of Identity in the Late Eighteenth Century Habsburg Monarchy", final manuscript version ("postprint") of book chapter in Gábor Almási \& Lav Subarić (eds.), Latin at the Crossroads of Identity: The Evolution of Linguistic Nationalism in the Kingdom of Hungary (Leiden: Brill, 2015), pp. 95118. (=Brill's book series Central and Eastern Europe: Regional Perspectives in Global Context, vol. 5)

This article revisits the complexities and ambivalences of the championing of the Latin language in combination with a sympathetic inquiry into the language and history of the Magyars by two Jesuit scholars of Hungarus stock during the heyday of Habsburg enlightened absolutism. In 1770, the Demonstratio idioma Ungarorum et Lapponum idem esse of Joannes (János) Sajnovics was published, arguing that the Lappian (or Saami, Sámi, Sami) language of the indigenous population of far-northern Norway in essence was the "same language" as Hungarian. This treatise was followed by theoretical deliberations by Sajnovics's mentor Maximilianus (Maximilian) Hell, who searched for the Hungarian - and Lappian- "Urheimat" in eastern Finland and north-western Russia, or perhaps even further east across the Urals to China. Both Sajnovics's treatise and Hell's inquiries became contested in late eighteenth-century Hungary. Furthermore, when Maximilian Hell embraced the Magyar cause and at the same time reasserted the status of Latin as the language of learned communication he also went against the tide of Viennese politics.

After introducing the two main characters of this chapter and outlining the "prehistory" of what is now established as Finno-Ugrian studies (an academic field in which Sajnovics's Demonstratio is generally rated highly), we shall briefly discuss the Central European reception of both Sajnovics's linguistic and Hell's historical contributions, attempting to locate them in the complex web of cultural sensitivities and political agendas in the late eighteenth-century Habsburg monarchy. This will be followed by a consideration of Hell's simultaneous and subsequent efforts to fend off the imperial promotion of German in public and academic communication at the expense of Latin. Taken together, the elaboration of these themes is intended to shed light on the predicament and scope of action of Hungarus Jesuit savants vis-à-vis the key actors of the political arena under Habsburg enlightened reform in the aftermath of the suppression of the Society of Jesus.

\section{Maximilianus (Maximilian) Hell and Joannes (János) Sajnovics}

Maximilian Hell (1720-1792) was born in a village just outside Banská Štiavnica (or Schemnicium, Schemnitz, Selmecbánya), the centre of a prosperous mining region in what 
Per Pippin Aspaas \& László Kontler, "Before and after 1773: Central European Jesuits, the Politics of Language and Discourses of Identity in the Late Eighteenth Century Habsburg Monarchy", final manuscript version ("postprint") of book chapter in Gábor Almási \& Lav Subarić (eds.), Latin at the Crossroads of Identity: The Evolution of Linguistic Nationalism in the Kingdom of Hungary (Leiden: Brill, 2015), pp. 95118. (=Brill's book series Central and Eastern Europe: Regional Perspectives in Global Context, vol. 5)

was then north Hungary, but is now in the middle of Slovakia. ${ }^{8}$ Both his parents were German-speaking; in fact his family name was Höll, not Hell. He was sent to the Jesuit schools (where he became fluent in Latin) and only as a 35-year-old did he start using the form Hell. Whether he ever learned Hungarian, and especially how fluently, is highly questionable, but he is recorded to have mastered a Slavic tongue, most probably Slovak. His Jesuit training took him from the heart of north Hungary to Vienna and then all across the Carpathian Basin to Transylvanian Cluj (Kolozsvár, Klausenburg, Claudiopolis). In 1755, he was called back to Vienna to become the Imperial and Royal Astronomer of Empress Maria Theresa. A highly prolific writer, Hell's working languages in his correspondence and printed publications were predominantly Latin, and especially in his later years German as well. As an ex-Jesuit, Hell retained his post as imperial astronomer and continued to issue various works in astronomy and related disciplines, his chef d'oeuvre being the Ephemerides Astronomicae ad Meridianum Vindobonensem, a large-format, combined astronomical almanac and scientific journal issued every year from 1757 onwards. ${ }^{9}$ Meanwhile, however, he had also developed an interest in the Hungarian language and in the historic origins of the Magyars.

In the year 1769, the planet Venus transited the disc of the Sun. The event offered a rare opportunity to measure the distance between the Sun and the Earth, and indeed the scale of the entire solar system. Caught up in a competition of imperial, royal and governmental patrons aiming to sponsor solutions to this scientific riddle, Hell was invited by the King of Denmark and Norway to undertake an expedition to the remote destination of Vardøhus (Vardø), a small island settlement on the north-easternmost coast of Norway. ${ }^{10}$ In this exotic

\footnotetext{
${ }^{8}$ The present biographical sketch is based on P. P. Aspaas, Maximilianus Hell (1720-1792) and the EighteenthCentury Transits of Venus: A Study of Jesuit Science in Nordic and Central European Contexts (Troms $\emptyset$ 2012), 45-182.

${ }^{9}$ For a full-scale analysis of Hell's Ephemerides, see L. Kontler, "The Uses of Knowledge and the Symbolic Map of the Enlightened Monarchy of the Habsburgs: Maximilian Hell as Imperial and Royal Astronomer (1755-1792)," in L. Kontler, A. Romano, S. Sebastiani and Zs. Török, eds., Negotiating Knowledge, Decentering Empires: The Sciences of Heavens, Earth, and Man, c. 1550-1810 (Basingstoke and New York 2014), 79-105.

${ }^{10}$ The expedition figures as an episode in Harry Woolf's standard The Transits of Venus: A Study of EighteenthCentury Science (Princeton 1959), as well as in several surveys occasioned by the 2004 and 2012 transits: E. Maor, June 4, 2004: Venus in Transit (Princeton 2004); W. Sheehan and J. Westfall, The Transits of Venus (Amherst 2004); C. Marlot, Les passages de Vénus: Histoire et observation d'un phénomène astronomique (Paris 2004); A. Wulf, Chasing Venus: The Race to Measure the Heavens (New York 2012). Most recently, see Aspaas, Maximilianus Hell, 184-341; id., "Maximilian Hellin ja Johannes Sajnovicsin 'Expeditio litteraria ad
} 
Per Pippin Aspaas \& László Kontler, "Before and after 1773: Central European Jesuits, the Politics of Language and Discourses of Identity in the Late Eighteenth Century Habsburg Monarchy", final manuscript version ("postprint") of book chapter in Gábor Almási \& Lav Subarić (eds.), Latin at the Crossroads of Identity: The Evolution of Linguistic Nationalism in the Kingdom of Hungary (Leiden: Brill, 2015), pp. 95118. (=Brill's book series Central and Eastern Europe: Regional Perspectives in Global Context, vol. 5)

region known as Lapland, however, it was not just the transit of Venus which was studied by Hell and his associates, notably his former pupil at the Viennese university observatory, János Sajnovics (1733-1785).

The very name Sajnovics betrays a Croat origin. ${ }^{11}$ The forefathers of János Sajnovics had immigrated to the central region of Hungary, where they became the holders of an estate (and a patent of petty nobility) in Tordas in Fejér County. Although Sajnovics in ethnic terms might be considered a Croat, he spoke Hungarian as his mother tongue. As a Jesuit priest, he was fluent in Latin and seems to have acquired a certain knowledge of German as well. As with many Hungari, Hell and Sajnovics communicated in Latin probably not only in their correspondence but also orally. Although Sajnovics had studied for some years in Vienna, where he assisted the imperial astronomer in his observatory, he had primarily been educated at Hungary's single university in Tyrnavia (Trnava, Tyrnau, Nagyszombat). His intimate knowledge of the Hungarian language was his only formal qualification for his landmark contribution to the history of comparative linguistics. During the expedition, Sajnovics made several interviews with Saami, or Lapps as they were called at the time. Thanks to these interviews, he ventured to prove earlier hypotheses that Hungarian and Saami belonged to the same language group, currently known as the Finno-Ugrian language family. On his way back from Norway, Sajnovics developed his theory into the impressive Demonstratio. The treatise was first published in Latin and Danish under the auspices of the Royal Society of Sciences in Copenhagen, where Hell and Sajnovics spent eight months during their return voyage from Vardøhus, and then it was reissued in an enhanced edition in Tyrnavia upon Sajnovics's return there in $1771 .^{12}$

Polum arcticum' ja suomalais-ugrilaisen kielentutkimuksen synty" [The "Expeditio litteraria ad Polum arcticum" of Maximilianus Hell and Joannes Sajnovics and the beginnings of Finno-Ugrian linguistics], in Lapin tuhat tarinaa, ed. by O. Pekonen and J. Stén (Ranua 2012), 65-86; L. Kontler, "Distances Celestial and Terrestrial: Maximilian Hell's Arctic Expedition, 1768-1769: Contexts and Responses," in The Practice of Knowledge and the Figure of the Savant in the 18th Century, ed. by A. Holenstein, H. Steinke and M. Stuber (Leiden 2013), 721-750.

${ }^{11}$ For a traditional biography, see E. Kisbán, Johann Sajnovics: Leben und Werk eines ungarischen Bahnbohrers und Gelehrten (Budapest 1943; orig. pub. in Hun. in 1942; also pub. in French in 1944); see further J. Erdődi, "Sajnovics, der Mensch und der Gelehrte," Acta Linguistica Academiae Scientiarum Hungaricae 20 (1970), 291-322. The most recent full biography is G. Lakó, János Sajnovics (Budapest 1983). Briefly in Eng., see Aspaas, Maximilianus Hell, esp. 116-120 (with references).

${ }^{12}$ J. Sajnovics, Demonstratio: Idioma Ungarorum et Lapponum idem esse ([Hafniae] [1770]); id., "Beviis, at Ungarernes og Lappernes Sprog er det samme," Skrifter som udi det Kiøbenhavnske Selskab af Lardoms og 
Per Pippin Aspaas \& László Kontler, "Before and after 1773: Central European Jesuits, the Politics of Language and Discourses of Identity in the Late Eighteenth Century Habsburg Monarchy", final manuscript version ("postprint") of book chapter in Gábor Almási \& Lav Subarić (eds.), Latin at the Crossroads of Identity: The Evolution of Linguistic Nationalism in the Kingdom of Hungary (Leiden: Brill, 2015), pp. 95118. (=Brill's book series Central and Eastern Europe: Regional Perspectives in Global Context, vol. 5)

Having just published the second edition of the Demonstratio, Sajnovics wrote in an optimistic letter to a Jesuit colleague that he now hoped to become "the Royal astronomer of Hungary." This position, it seems, was envisaged for him by Father Hell, who planned to have a new observatory constructed in conjunction with the Jesuit collegium in Buda. ${ }^{13}$ This did not come about. Sajnovics returned to his home university in Tyrnavia where he carried on a career as an assistant of the older Jesuit astronomer Franciscus (Ferenc) Weiss. Later, when the university observatory of Tyrnavia was moved to Buda (1777), Sajnovics followed Weiss there. Sajnovics survived Weiss by only half a year, and died in 1785. His only scientific publication was a rather unambitious textbook of astronomy, the Idea Astronomiae (Buda 1778).

\section{The prehistory of Finno-Ugrian linguistics}

Finno-Ugrian language studies is by now a long-established academic discipline. Although the term "Finno-Ugrian" (or Finno-Ugric) was not coined until the nineteenth century, the roots of the concept reach back into the seventeenth century. ${ }^{14}$ One of the earliest academic texts arguing for a linguistic link between several of the languages now considered FinnoUgrian was written by Martin Fogel(ius) of Hamburg, De lingua indole Finica observationes (1669). More seminal were probably the arguments that Gottfried Wilhelm Leibniz and his collaborator, Johann Georg von Eckhart, put forward in the early eighteenth century. Leibniz argued for a large-scale collection of samples from various vernaculars, not least in Russia. In this context, he pointed to a supposed connection between Saami, Finnish, Hungarian and several indigenous languages found in the Russian realm. ${ }^{15}$ Collection of linguistic data from Russia did not begin in earnest until the 1720s, nevertheless. Several expeditions were then dispatched to chart the Russian Empire, with linguistic studies forming part of the research

Videnskabers Elskere ere fremlagte og oplaeste 10 (1770), 653-732; id., Demonstratio: Idioma Ungarorum et Lapponum idem esse ([Tyrnaviae] [1771]). The year of publication is missing on the title page of both Latin editions. For a source-based discussion of the two versions and their relation to each other, see Aspaas, Maximilianus Hell, 117-132.

${ }^{13}$ Aspaas, Maximilianus Hell, 168.

${ }^{14}$ For a standard narrative of the early modern roots of Finno-Ugrian linguistics, see G. J. Stipa, Finnischugrische Sprachforschung: Von der Renaissance bis zum Neupositivismus (Helsinki 1990).

${ }^{15}$ G. G. Leibnitius, "Brevis designatio meditationum de Originibus Gentium, ductis potissimum ex indicio linguarum," Miscellanea Berolinensia ad Incrementum Scientiarum, ex Scriptis Societati Regiae Scientiarum exhibitis edita 1 (1710), 1-16, cf. Stipa, Finnisch-ugrische Sprachforschung, 155-164; H. Arens, Sprachwissenschaft: Der Gang ihrer Entwicklung von der Antike bis zur Gegenwart, 2nd edn. (Munich 1969), 94-104. 
Per Pippin Aspaas \& László Kontler, "Before and after 1773: Central European Jesuits, the Politics of Language and Discourses of Identity in the Late Eighteenth Century Habsburg Monarchy", final manuscript version ("postprint") of book chapter in Gábor Almási \& Lav Subarić (eds.), Latin at the Crossroads of Identity: The Evolution of Linguistic Nationalism in the Kingdom of Hungary (Leiden: Brill, 2015), pp. 95118. (=Brill's book series Central and Eastern Europe: Regional Perspectives in Global Context, vol. 5)

programmes. A German-speaking Swedish general who had been taken captive and sent to Siberia, Philipp Johann von Strahlenberg, took part in one of the earliest expeditions. Having been released, he published a sensational book on the northern and eastern parts of Russia (1730). ${ }^{16}$ In his book, Strahlenberg included a table with words from what he defined as "the Tatarian and Hunno-Scythian ancestral peoples." All the languages he included in the table are now considered part of the Uralic language family, of which the Finno-Ugrian group (or, as he called it, the "Hun nation") constitutes the largest branch. Mutatis mutandis, Strahlenberg perceived the linguistic links between the entire group of Finno-Ugrian peoples, with members from Siberia (Mansi, Khanty) via north-west Russia (Komi, Mari, Mordvin, etc.) and the Baltics (Estonian, Livonian) to Central Europe (Magyar) and Fennoscandinavia (Saami, Finnish, Karelian). ${ }^{17}$ Further contributions in the decades following Strahlenberg added more empirical evidence and presented new theories on the ethnic origins of the Magyars. Some of the most comprehensive works were by Johann Eberhard Fischer and August Ludwig Schlözer, both German historians who had spent years working at the St Petersburg Academy of Sciences. Their main works on Finno-Ugrian subject matters were published in the same period as Sajnovics's Demonstratio. ${ }^{18}$

It is important to note, however, that for all the evidence-based theories that were put forward, a perceived linguistic — and hence ethnic_-kinship between the Magyars and other nations of the Finno-Ugrian family was by no means unanimously accepted in eighteenthcentury Europe. For one thing, to borrow terms from Kristian Nilsson's recent PhD thesis,

\footnotetext{
${ }^{16}$ P. J. von Strahlenberg, Das Nord- und Ostliche Theil von Europa und Asia, Jn so weit solches Das gantze Rußische Reich mit Siberien und der grossen Tatarey in sich begreiffet, Jn einer Historisch-Geographischen Beschreibung der alten und neuern Zeiten, und vielen andern unbekannten Nachrichten vorgestellet, Nebst einer noch niemahls ans Licht gegebenen Tabula Polyglotta von zwey und dreyßigerley Arten Tatarischer Völcker Sprachen und einem Kalmuckischen Vocabulario, Sonderlich aber Einer grossen richtigen Land-Charte von den benannten Ländern und andern verschiedenen Kupfferstichen, so die Asiatisch-Scythische Antiqvität betreffen; Bey Gelegenheit der Schwedischen Kriegs-Gefangenschafft in Rußland, aus eigener sorgfältigen Erkundigung, auf denen verstatteten weiten Reisen zusammen gebracht und ausgefertiget (Stockholm 1730). ${ }^{17}$ It might be added that modern archival studies have revealed that his book was not published in compliance with intellectual property rights, as the entire book relied heavily on materials collected by another participant of the same expedition, Daniel Gottlieb Messerschmidt. See Stipa, Finnisch-ugrische Sprachforschung, 173-179.

${ }^{18}$ J. E. Fischer, Sibirische Geschichte von der Entdeckung Sibiriens bis auf die Eroberung dieses Landes durch die Russische Waffen (Sankt Petersburg 1768); id., Quaestiones Petropolitanae I. De origine Ungrorum. II. De origine Tatarorum. III. De diversis Sinarum imperatoris nominibus titulisque IV. De Hyperboreis, ed. A. L. Schlözer ([Gottingae] 1770); A. L. Schlözer, Allgemeine Nordische Geschichte: Aus den Neuesten und Besten Nordischen Schriftstellern und nach Eigenen Untersuchungen Beschrieben, und als eine Geographische und Historische Einleitung zur Richtigern Kenntniß Aller Skandinavischen, Finnischen, Slavischen, Lettischen und Sibirischen Völker, besonders in alten und mittleren Zeiten (Göttingen 1771).
} 
Per Pippin Aspaas \& László Kontler, "Before and after 1773: Central European Jesuits, the Politics of Language and Discourses of Identity in the Late Eighteenth Century Habsburg Monarchy", final manuscript version ("postprint") of book chapter in Gábor Almási \& Lav Subarić (eds.), Latin at the Crossroads of Identity: The Evolution of Linguistic Nationalism in the Kingdom of Hungary (Leiden: Brill, 2015), pp. 95118. (=Brill's book series Central and Eastern Europe: Regional Perspectives in Global Context, vol. 5)

both Biblical and literary ethnohistory co-existed alongside more linguistically oriented modes of ethnohistorical inquiry. Biblical and literary ethnohistories would find evidence in the Bible or other authoritative texts, usually from Greco-Roman antiquity or the Middle Ages, whereas linguistic ethnohistory would search for origins and kinships between different ethnic groups by means of arguments taken from a (methodologically more or less sound) comparison of languages. ${ }^{19}$ In this period of transition, before the differentiation of the humanities and social sciences into a variety of research disciplines, several types of ethnohistory were often mixed together in one work, and it was not always perceived to be self-evident that more weight was to be lent to linguistic evidence than to other kinds of sources. What is more, even those who adhered to the methods of linguistic ethnohistory could differ substantially in their conclusions. ${ }^{20}$

Three examples from the international republic of letters must suffice here. In the Harmonia linguarum Orientis et Occidentis speciatim Hungaricae cum Hebraea (Wittenberg 1746) of the Hungarian Joannes Gottofredus Oertelius, vigorous arguments are put forward against Leibniz, Eckhart and others, who allegedly spoiled the "great heritage of the Magyars" by linking them partly to Siberia, Scandinavia, Finland or Mordvania, and partly to a mixture of all these regions. ${ }^{21}$ Oertelius' response was to link the Hungarian language — and by implication, the Hungarian nation itself- to Hebrew. This idea was not at all new, ${ }^{22}$ but it

\footnotetext{
${ }^{19}$ For these concepts, see Kr. Nilsson, Baltic-Finns and Scandinavians: Comparative-Historical Linguistics and the Early History of the Nordic Region, Ugglan - Minervaserien 16 (Lund 2012). A fourth type of ethnohistory singled out by Nilsson, "lingual ethnohistory," is difficult to differentiate from linguistic ethnohistory. If we interpret him correctly, lingual ethnohistory implies studying a single language to find evidence for prehistorical ways of living within its vocabulary (e.g. a refined and rich agricultural vocabulary would suggest a long history of farming). Linguistic ethnohistory, by contrast, is concerned with comparing two or more languages with each other in search of evidence for ethnic kinship and migrations.

20 This remark appears necessary, since several much-quoted surveys of the history of Finno-Ugrian linguistics in our view are somewhat exaggeratory in their characterisations of the Finno-Ugrian theory as a widely acknowledged scientific "discovery" already by the mid-eighteenth century, cf. e.g. M. Korhonen, FinnoUgrian Language Studies in Finland 1828-1918 (Helsinki 1986), 30.

${ }^{21}$ I. G. Oertelius, Harmonia LL. orientis et occidentis speciatimque Hungaricae cum Hebraea, ed. I. Hlivai (Wittenberg 1746), editor's preface, iii-ix.

${ }^{22}$ Comparing (nearly any) modern language with Hebrew was a topos in academic theories of linguistic kinship during the sixteenth and seventeenth centuries, partly because of the authority of the Bible in ethnohistorical inquiry (cf. Nilsson's concept of Biblical ethnohistory, above), and partly because of the prestige it lent to a people to be associated with what was then widely recognised as the "oldest language of the world" (cf. Arens, Sprachwissenschaft, 69-70). As regards the Hungarian language's alleged link to Hebrew, following Melanchthon and other German Protestant scholars, it became quite widespread among fellow Hungarian Protestants in the sixteenth and seventeenth centuries. See G. Tóth, "Civilizált"” östörténet. A magyar nyelv és a magyar nemzet eredetének kutatása Bél Mátyás életmüvében” [“Civilised” ancient history. The search for the
} 
Per Pippin Aspaas \& László Kontler, "Before and after 1773: Central European Jesuits, the Politics of Language and Discourses of Identity in the Late Eighteenth Century Habsburg Monarchy", final manuscript version ("postprint") of book chapter in Gábor Almási \& Lav Subarić (eds.), Latin at the Crossroads of Identity: The Evolution of Linguistic Nationalism in the Kingdom of Hungary (Leiden: Brill, 2015), pp. 95118. (=Brill's book series Central and Eastern Europe: Regional Perspectives in Global Context, vol. 5)

is intriguing to note that Oertelius employed a set of recognizably linguistic criteria in setting forth his argument: syntax, morphology, phonetics, etymology. At around the same time, the German-speaking Silesian Gottfried Hensel(ius) published an ambitious Synopsis universae philologiae, in qua miranda unitas et harmonia linguarum totius orbis terrarum occulta, $e$ literarum, syllabarum, vocumque natura et recessibus, eruitur (Nuremberg 1741). While praising Leibniz as inspirer of his work, Hensel hardly follows his theories concerning the Finno-Ugrian languages. Thus, he implicitly describes Hungarian as belonging to what he calls the "Illirico-Sclavonica" group of languages. In a map accompanying his book, most languages of Europe are graphically presented in the form of the first sentence of the Lord's Prayer. Three groups are designated: the "Progenies Hellenica," the "Celto-Theotisca" and the "Illirico-Sclavonica" groups. But whereas the Hungarian language is explicitly included in the last-mentioned group both on the map and in the book itself, the status of Finnish and Saami is more obscure (a comment on the map, which seems to refer to both Finnish and Saami, reads "Sclavonico-mixta"). ${ }^{23}$ In addition to Oertelius and Hensel, a work by the Danish theologian Marcus Wöldike, Betcenkning om det Grønlanske Sprogs Oprindelse og Uliighed med andre Sprog (Reflections regarding the origin and uniqueness of the Greenlandic language as compared with other languages, 1746), is worthy of mention. Basing himself upon a dictionary and a grammar of Greenlandic (Inuit) that had been compiled by a Danish-Norwegian missionary, Wöldike concluded that Greenlandic and Hungarian had a common origin, which he believed to be located in Tartaria:

There is, then, as far as the grammar is concerned, only negligible similarity between Greenlandic and the European languages, except Hungarian, and it is quite striking and noteworthy, that exactly in those elements where the Hungarian language differs from the other European ones, is where it is in accordance with the Greenlandic language [...]. I dare not, however, based upon these facts draw the conclusion that the Hungarian and the Greenlandic languages at some stage have been one and the same, as the dissimilarities in the vocabulary between the two languages are too enormous for that. The

origins of the Hungarian language and the Hungarian nation in the oeuvre of Mátyás Bél], Történelmi Szemle 54, no. 2 (2012), 219-246. See also Z. Vladár, “Sajnovics’ Demonstratio and Gyarmathi’s Affinitas:

Terminology and Methodology," Acta Linguistica Hungarica 55 (2008), 145-181, at 147-149.

${ }^{23}$ Hensel, Synopsis universae philologiae, map entitled "EVROPA POLYGLOTTA Linguarum Genealogiam exhibens, una cum Literis, scribendique modis, Omnium Gentium." 
Per Pippin Aspaas \& László Kontler, "Before and after 1773: Central European Jesuits, the Politics of Language and Discourses of Identity in the Late Eighteenth Century Habsburg Monarchy", final manuscript version ("postprint") of book chapter in Gábor Almási \& Lav Subarić (eds.), Latin at the Crossroads of Identity: The Evolution of Linguistic Nationalism in the Kingdom of Hungary (Leiden: Brill, 2015), pp. 95118. (=Brill's book series Central and Eastern Europe: Regional Perspectives in Global Context, vol. 5)

only thing I dare maintain is that they must originate from an area or part of the world, which I suppose to be the vast Tartaria. $^{24}$

Thus, Wöldike follows neither Oertelius' assertion of a Hungarian-Hebrew connection nor Hensel's classification of Hungarian as an "Illyric" (Slavic) language. Instead, he points to the region of Tartaria as a distant but common origin of both Greenlandic and Hungarian.

As we have seen, Oertelius (1746), Hensel (1741) and Wöldike (1746) all discussed the Hungarian language, they all employed methodologies recognizable as linguistic ethnohistory, and while in disagreement among themselves, they were also in disagreement with the Finno-Ugrian theories that had already been put forward by Fogel, Leibniz, Eckhart and Strahlenberg between the 1680s and 1730s. Such was the situation internationally when Sajnovics undertook his studies of Saami and Hungarian in far-northern Vardøhus. As for the Central European and Hungarian intellectual landscape, the Stand der Forschung was not merely less oriented towards linguistic ethnohistory, it was also more recognizably charged with ideological undertones characteristic of an identity discourse. Before this topic is briefly discussed, it is necessary to explore the nature of the contributions of Sajnovics and Hell.

\section{The Demonstratio and the Expeditio}

Sajnovics seems to have felt that the title of his treatise- "Demonstration that the Hungarian and Lapponian Language is the Same"-boasted a bit more than it could deliver. In the opening part of the Demonstratio he was quick to explain that the expression idioma idem implied that Hungarian and Saami were two dialects of the same language. In a distant past, more precisely in the fourth century, the Hungarians and the Saami had spoken the same dialect. However, since then the two groups had migrated in opposite directions and lived in

\footnotetext{
${ }^{24}$ M. Wöldike, "Betænkning om det Grønlanske Sprogs Oprindelse og Uliighed med andre Sprog” [Reflections regarding the origin and uniqueness of the Greenlandic language as compared with other languages], Skrifter som udi det Kiфbenhavnske Selskab af Lardoms og Videnskabers Elskere ere fremlagte og oplaste 2 (1746), 129-156, at 151: "Saa findes der da i henseende til Grammaticam saare liden Overeenstemmelse imellem det Grønlandske og de Europæiske Sprog, undtagen det Hungariske, og det er gandske besynderligt og mærkeligt, at just i de Poster, hvorudi det Hungariske Sprog differerer fra de andre Europæiske, derudi kommer det overeens med det Grønlandske [...]. Men heraf tør jeg dog ingenlunde giøre den Slutning, at det Hungariske og Grønlandske Sprog nogensinde har været et og det samme, saasom der er alt for stor Forskiel imellem Gloserne i begge disse Sprog, men ikkun det, at de maa være komne fra en Egn eller fra en deel i Verden, som jeg mener at skulle være det store Tartarie.” For more on Wöldike's work, see G. Lakó, "Von der Frage nach Beziehungen der Eskimosprache zum Ungarischen bis zur Erschliessung der Ungarisch-Lappischen Sprachverwandtschaft," Fenno-Ugrica Suecana 2 (1979), 75-84.
} 
Per Pippin Aspaas \& László Kontler, "Before and after 1773: Central European Jesuits, the Politics of Language and Discourses of Identity in the Late Eighteenth Century Habsburg Monarchy", final manuscript version ("postprint") of book chapter in Gábor Almási \& Lav Subarić (eds.), Latin at the Crossroads of Identity: The Evolution of Linguistic Nationalism in the Kingdom of Hungary (Leiden: Brill, 2015), pp. 95118. (=Brill's book series Central and Eastern Europe: Regional Perspectives in Global Context, vol. 5)

total separation from each other. During the long period of separation their language had changed considerably both in Lapland and in Central Europe, so that the two dialects were no longer mutually intelligible. Sajnovics proceeds by pointing to analogous examples: Italian, Spanish and French are all dialects of Latin, whereas Danish, Dutch — and English—are dialects of German, just as Russian, Polish and Bohemian are dialects of the so-called Illyric language. Hungarian and Saami are thus only dialects of an older, lost language that he calls the Lingua Fennica. ${ }^{25}$ That is about as much as the first edition of the Demonstratio contains concerning the historical background for the linguistic connection between Hungarian and Saami. The rest of the text is concerned with a systematically built argument which has been described as permeated by an astonishingly sound and innovative methodology that foreshadows later developments within a discipline now known as comparative linguistics. ${ }^{26}$ Sajnovics himself, while admitting that others had presented similar theories, argued in the final chapter of his treatise that he "could not claim the honour of having made the discovery, but perhaps rather that of certifying and demonstrating it." 27

Sajnovics quickly received considerable prestige in the German and Nordic parts of Europe. Thus, the above-mentioned Göttingen historian A. L. Schlözer reviewed Sajnovics's Demonstratio positively in his Allgemeine Nordische Geschichte (1771), and two leading historian/linguists in Åbo (Turku) and Uppsala respectively, Henrik Gabriel Porthan and Johannes (Johan) Ihre, embraced his achievement in publications from 1771-72. ${ }^{28}$ However, apart from the compelling display of linguistic methodology, there were other aspects of the Demonstratio that soon proved problematic, even in a Nordic context. Sajnovics argued, without success, that the Saami orthography, which had been developed by a senior Norwegian priest named Leem, ${ }^{29}$ should be replaced by the Hungarian system of spelling.

\footnotetext{
${ }^{25}$ Sajnovics, Demonstratio, 1st edn., [1]-4.

${ }^{26}$ E.g. Gy. Décsy and W. Veenker's "Nachwort" to the German translation of the Demonstratio: J. Sajnovics, Beweis, daß die Sprache der Ungarn und Lappen dieselbe ist (Wiesbaden 1972), 159-163. A more cautious assessment in Vladár, "Sajnovics' Demonstratio."

${ }^{27}$ Sajnovics, Demonstratio, 1st edn., 73-74 (repeated in 2nd edn., 111): "Idioma Ungaricum cum Fennico, atque Lapponico convenire etsi non demonstrent [scil. opuscula aliorum], ita tamen luculenter asserunt, ut hac in re novae Inventionis laudem mihi arrogare non possim, licet forte possem certitudinis, atque Demonstrationis." ${ }^{28}$ Schlözer, Allgemeine Nordische Geschichte, 306-307; H. G. Porthan, Tidningar Utgifne Af et Sällskap i Åbo 1 (1771), 3-8, 61-62, 138-141, 148-150, 180-181, 186-188; J. Ihre (praeses) and E. J. Öhrling (respondens), Dissertatio Academica de Convenientia Lingvae Hungaricae cum Lapponica ([Upsaliae] 1772).

${ }^{29}$ Knud Leem (1697-1774) had served as a missionary in Finnmark, the northernmost county of Norway in the $1720 \mathrm{~s}$ and 1730s. Based on materials that he assembled as a missionary, he produced a Saami grammar (En
} 
Per Pippin Aspaas \& László Kontler, "Before and after 1773: Central European Jesuits, the Politics of Language and Discourses of Identity in the Late Eighteenth Century Habsburg Monarchy", final manuscript version ("postprint") of book chapter in Gábor Almási \& Lav Subarić (eds.), Latin at the Crossroads of Identity: The Evolution of Linguistic Nationalism in the Kingdom of Hungary (Leiden: Brill, 2015), pp. 95118. (=Brill's book series Central and Eastern Europe: Regional Perspectives in Global Context, vol. 5)

His argument was quite straightforward: since Hungarian and Saami are really just two forms of the same language, one should use the same orthography. ${ }^{30}$ While in Copenhagen in the winter of 1769/70, Hell and Sajnovics managed to gain the support of the minister Otto Thott for this idea. Upon Thott's orders, one of the very few native Saami priests with university exams in Denmark-Norway, Anders Porsanger, was called from Trondheim in Norway to Copenhagen. Here Porsanger collaborated closely with Sajnovics on the project of supplanting Leem's orthography with a Hungarian version, besides giving advice that Sajnovics ultimately was to include in the second edition of his Demonstratio. ${ }^{31}$ This effort failed, primarily due to political problems in Copenhagen (Thott was removed from his offices in the autumn of 1770), but also because of resistance within Danish-Norwegian ecclesiastic circles. ${ }^{32}$ Another corollary of the discovery of the so-called identity of Hungarian and Saami was that the two languages ought to exploit each other's lexicons to enrich their vocabulary. So, instead of importing loan words from Latin, Italian and German, Sajnovics argued that the Hungarians should look for truly Hungarian words in the vocabulary of its "sister nation" in the Far North. ${ }^{33}$ Little came out of this, with one notable

Lappisk Grammatica: Efter den Dialect, som bruges af Field-Lapperne udi Porsanger-Fiorden [Kiøbenhavn 1748]) and a Danish-Saami vocabulary (En Lappesk Nomenclator efter Den Dialect, som bruges af FjeldLapperne i Porsanger-Fjorden [Tronhiem 1756]), followed by a richly illustrated, bilingual ethnographic description of the Saami (Beskrivelse over Finmarkens Lapper, deres Tungemaal, Levemaade og forrige Afgudsdyrkelse / De Lapponibus Finmarchiae, eorumque lingua, vita et religione pristina commentatio [Kiøbenhavn 1767]) and a Saami-Danish-Latin and Danish-Latin-Saami dictionary (Lexicon Lapponicum bipartitum: Lapponico-Danico-Latinum et Danico-Latin-Lapponicum [Nidrosiae 1768-1780]). From 1752 to his death, Leem served as a professor linguae Lapponicae at a special seminar in Trondheim with the task of preparing Danish-Norwegian priests for service in Saami regions of Norway, cf. e.g. J. R. Hagland and S. Supphellen, eds., Knud Leem og det samiske [Knud Leem and Saami issues], Det Kongelige Norske Videnskabers Selskab Skrifter (Trondheim 2003). When Hell and Sajnovics passed through Trondheim on their way back and forth to Vardøhus, they seem to have met Leem only once, and certainly did not develop any direct collaboration with him, cf. Sajnovics's manuscript travel diary covering 1768-1770 (Wiener Universitätssternwarte, Vienna, Manuscripte von Hell), entry on 7 September 1769. Instead, Sajnovics collaborated closely with Leem's Saami assistant Anders Porsanger (see below).

${ }^{30}$ Sajnovics, Demonstratio, 1st edn., 17-25 (slightly revised and expanded in 2nd edn., 25-41).

${ }^{31}$ See Sajnovics, Demonstratio, 2nd edn., 34-38. For a source-based investigation of the relationship between Sajnovics and Porsanger, see B. Martinussen, “Anders Porsanger: teolog og språkforsker fra 1700-tallets Finnmark" [Anders Porsanger: Theologian and Linguist from 18th-century Finnmark], Nordlyd 18 (1992), 1559, summarised in English in E. Hovdhaugen, F. Karlsson, C. Henriksen and B. Sigurd, The History of Linguistics in the Nordic Countries (Helsinki 2000), 54-55.

${ }^{32}$ See P. P. Aspaas, "Den gang samene (nesten) ble Nord-Europas ur-ungarere: Johannes Sajnovics's Demonstratio (1770) og dens resepsjon" [When the Saami (almost) became the Ur-Ungarians of the European North: The Demonstratio of Johannes Sajnovics (1770) and its Reception] (forthcoming article).

${ }^{33}$ Sajnovics, Demonstratio, 2nd edn., 79-83. 
Per Pippin Aspaas \& László Kontler, "Before and after 1773: Central European Jesuits, the Politics of Language and Discourses of Identity in the Late Eighteenth Century Habsburg Monarchy", final manuscript version ("postprint") of book chapter in Gábor Almási \& Lav Subarić (eds.), Latin at the Crossroads of Identity: The Evolution of Linguistic Nationalism in the Kingdom of Hungary (Leiden: Brill, 2015), pp. 95118. (=Brill's book series Central and Eastern Europe: Regional Perspectives in Global Context, vol. 5)

exception. It is recorded in the second edition of the Demonstratio that Sajnovics paid a visit to the Hungarian Jesuit poet Franciscus (Ferenc) Faludi upon his return to Hungary:

When I recently visited Honourable Father Faludi's in Posonium [Pressburg, Pozsony, Bratislava], and showed him my manuscripts for him to inspect, the first that his eyes fell upon was the Latin word forma, exemplar, modulus. The Hungarians call this by the Latin loanword forma, whereas the Lapps call it minta, and in doing so speak more Hungarian than we do, for a modulus would have been quite correctly called a minta by the Hungarians, in the sense: "just like that." 34

According to the editors of the German translation of Sajnovics's treatise, this is the only word that has entered Hungarian usage following Sajnovics's recommendation. The irony of the story is that the word minta is no more Finno-Ugrian than forma, but derived from the Scandinavian word mynt, or "coin" (compare the German word Münze)! ${ }^{35}$ However, the mention of Faludi is effectively a case of efficient name-dropping. Sajnovics employs this frequently in his treatise, partly as a token of gratitude, partly - as here - as a means to lend weight to his argument. Especially in the second edition of the Demonstratio there are references to a number of Hungarian contemporaries who have expressed their support. Most conspicuous is the invocation of the Empress Maria Theresa herself as protector of the investigation of "Hungarian origins" that Hell has begun. ${ }^{36}$

Whilst Sajnovics made his revision of the Demonstratio in Tyrnavia, Hell sat in Vienna working out a huge plan for a three-volume encyclopaedia on the Far North-the Expeditio Litteraria ad Polum Arcticum. In this grand folio work, he envisaged including both the report of his expedition and its various scientific results, including a Tomus Historicus: an ethnographic, linguistic and historical account of the region. ${ }^{37}$ Sajnovics's Demonstratio would of course find its place therein.

\footnotetext{
${ }^{34}$ Sajnovics, Demonstratio, 2nd edn., 80: "Nuper dum Posonii apud R. Patrem FALUDI versarer, eique mea manuscripta obiter inspicienda porrigerem, primo intuitu in vocem latinam forma, exemplar, modulus incidit. Ungari id vocant, a latinis mutuato vocabulo Forma, sed Lappones dicunt Minta, magis certe Ungarice quam nos, modulus enim ab Ungaris rectissime diceretur Minta, seu sicut illud."

${ }^{35}$ Sajnovics, Beweis, 149, endnote 30 (the modern Hungarian equivalent being mind az or mint $a$ ).

${ }^{36}$ Sajnovics, Demonstratio, 2nd edn., 126-127.

${ }^{37}$ Early in 1771, Hell issued an invitation for subscriptions to the Expeditio, in which he summarised its contents. A critical edition of this text (with facing English translation and commentary) is found in Aspaas, Maximilianus Hell, 361-381.
} 
Per Pippin Aspaas \& László Kontler, "Before and after 1773: Central European Jesuits, the Politics of Language and Discourses of Identity in the Late Eighteenth Century Habsburg Monarchy", final manuscript version ("postprint") of book chapter in Gábor Almási \& Lav Subarić (eds.), Latin at the Crossroads of Identity: The Evolution of Linguistic Nationalism in the Kingdom of Hungary (Leiden: Brill, 2015), pp. 95118. (=Brill's book series Central and Eastern Europe: Regional Perspectives in Global Context, vol. 5)

Prior to Hell and Sajnovics, most Hungarian scholars as well as the social and educated elite adhered to the so-called "Scythian theory," which associated the ancestors of Hungarians with the warrior peoples of the Eurasian steppe. Maximilian Hell, by contrast, located the "Urheimat" of the Hungarians - and the Saami-in north-west Russia. On a special map of Karelia, which was intended to be included in the Expeditio, he showed the original dwellings of various tribes described in a work that had a profound inspiration on his imagination, the Gesta Hungarorum of the thirteenth century (see FIGURE). The names of all the eight Hungarian tribes described in this medieval chronicle were, as Hell saw it, retrievable in slightly altered forms in north-west Russia, where they designated various rivers and lakes whence the ancient tribes supposedly had derived their names. It was precisely from this area between Lake Ladoga and the White Sea that the Hungarians according to Hell's theory had wandered south to take root in Central Europe. This explanation was not sufficient, however. Hell also argued that the existence of related languages in other parts of Russia proved that their ancestry stretched even further east. Hungarian was in fact a distant relative of Chinese! ${ }^{38}$ The Expeditio was never published in its entirety. His theory can, however, be reconstructed from various unfinished manuscripts and correspondence. An addition, which is cast as the summary of a letter from Hell and inserted into the second edition of the Demonstratio, gives evidence of Hell's theory as it stood in the winter of $1770 / 71 .^{39}$

In general terms, it might be said that whereas the Demonstratio restricted itself to proving the linguistic link between Hungarian and Saami, the Expeditio was meant to present a theory on the historical background to this linguistic link. Where Sajnovics merely demonstrated the existence of linguistic affinity, Hell sought to explain how this affinity had

\footnotetext{
${ }^{38}$ Evidence for the alleged Chinese origins Hell found in the root Same, visible in the designation used by the Saami to denote themselves and by the Russians as an ethnonym for the Samojeds (Nenets); see Hell's letter from Vienna to G. Pray in Posonium, dated 4 January 1771 (ELTE University Library, Budapest, MS G 119, no. 168b-c): "Maximo gaudio exultabam, dum intellexi R[everentiam] V[est]ram ejusdem mecum esse Sententiae de idiomate Sinensium tanquam Matre idiomatis asiatici, hoc est, Fennici, Lapponici, Ungarici etc: ex hac enim idiomatis convenientia fortissimum reperi argumentum, Lappones, Samojedas, et universim omnes populos Septentrionales Europae lingua fennica utentes olim ante ter, vel quater mille annos terras inhabitâsse illas, quae sinensium muro ad septentrionem proximae Sunt, quas sinenses Lop. et Tartari samo appellant, Lappones enim seipsos compellant Same aut Samalez, aut Samelim etc: id est, è Regione Samo prognatos.”

${ }^{39}$ Sajnovics, Demonstratio, 2nd edn., 119-126. The very summary of the "letter" was actually not only composed by Hell, but sent to Tyrnavia accompanied with very specific instructions regarding exactly where and how it was to be inserted into Sajnovics's work, cf. Aspaas, Maximilianus Hell, 117-131.
} 
Per Pippin Aspaas \& László Kontler, "Before and after 1773: Central European Jesuits, the Politics of Language and Discourses of Identity in the Late Eighteenth Century Habsburg Monarchy", final manuscript version ("postprint") of book chapter in Gábor Almási \& Lav Subarić (eds.), Latin at the Crossroads of Identity: The Evolution of Linguistic Nationalism in the Kingdom of Hungary (Leiden: Brill, 2015), pp. 95118. (=Brill's book series Central and Eastern Europe: Regional Perspectives in Global Context, vol. 5)

come about. In doing so, Hell shifted not only from linguistic ethnohistory to literary ethnohistory (using the Demonstratio merely as a springboard, he soon relied on literary works such as the anonymous Gesta Hungarorum or Constantine Porphyrogenitus' De administrando imperio as main evidence), ${ }^{40}$ he also transgressed one of the rules that Sajnovics had so meticulously followed in the Demonstratio. Sajnovics argued that one should never rely on written evidence alone, but always find native speakers to pronounce each word to verify how it was actually pronounced. For in this age before the invention of the International Phonetic Alphabet, what looked like striking similarities on paper often turned out to be anything but similar when pronounced by a native speaker and vice versa: native speakers sometimes pronounced words quite differently to the (often arbitrary) orthography which had been used to write them down, revealing similarities that seemed not to be there when judged from the spelling used in books. ${ }^{41}$ Discarding such scruples, Hell in his historical chapters of the projected Expeditio employed a variety of sources-ranging from Dutch cartography via French historical works to the above-mentioned medieval chronicles - in a search for striking similarities. Sometimes, when striking similarities were hard to come by, he would "translate" ethnonyms to serve his purposes. As Hell explained in several letters to his colleague, the Hungarian Jesuit historian Georgius (György) Pray, the Cházaroi of Constantine Porphyrogenitus and the Cumani of the Gesta Hungarorum were one and the same people. He also repeatedly argued that Turkic-speaking tribes had mixed with the Magyars and become Magyarised. ${ }^{42}$ And when confronted with explicit literary evidence for a Scythian ancestry of the Cumani, he at one point exclaimed, "I do not see why Scythia, a word of such wide significance, cannot be applied to Finland and Karelia?" 43

\footnotetext{
${ }^{40}$ For modern editions of these works, see Anonymus, Anonymi Bele regis notarii Gesta Hungarorum / Anonymus, Notary of King Béla, The Deeds of the Hungarians, ed. by M. Rady and L. Veszprémy; and Master Roger, Magistri Rogerii Epistola in miserabile carmen super destructione Regni Hungarie per tartaros facta I Master Roger's Epistle to the Sorrowful Lament upon the Destruction of the Kingdom of Hungary by the Tatars, ed. by J. M. Bak and M. Rady, Central European Medieval Texts 5 (Budapest 2010); Constantine Porphyrogenitus, De administrando imperio, ed. by G. Moravcsik and R. J. H. Jenkins, Dumbarton Oaks texts 1 (Washington, D.C. 1966).

${ }^{41}$ Sajnovics, Demonstratio, 1st edn., 8-13 (slightly expanded and revised in 2nd edn., 14-19).

${ }^{42}$ Hell in letters to Pray in Posonium, esp. letters dated Vienna 29 March and 13 June 1771 (ELTE University Library, Budapest, MS G 119, no. 163 and 165).

${ }^{43}$ Hell, in an undated comment to G. Pray's manuscript Observationes in Systema P. Maximiliani Hell (ELTE University Library, Budapest, Coll. Prayana XVIII. 23): "Scythia, vox amplissimae significationis non video, cur Finnlandiæ, et Carjeliæ applicari non possit?"
} 
Per Pippin Aspaas \& László Kontler, "Before and after 1773: Central European Jesuits, the Politics of Language and Discourses of Identity in the Late Eighteenth Century Habsburg Monarchy", final manuscript version ("postprint") of book chapter in Gábor Almási \& Lav Subarić (eds.), Latin at the Crossroads of Identity: The Evolution of Linguistic Nationalism in the Kingdom of Hungary (Leiden: Brill, 2015), pp. 95118. (=Brill's book series Central and Eastern Europe: Regional Perspectives in Global Context, vol. 5)

Maximilian Hell's grand Expeditio was never accomplished. Hell soon found himself absorbed in a heated controversy over the calculation of the solar distance and his own Venus transit observations' usage therein; a commission for the possible establishment of an Austrian Academy of Sciences also took up much of his time and energy in the mid-1770s. According to his own account, the sudden dissolution of the Society of Jesus also robbed him of his assistants, forcing him to do all his astronomical tasks on his own, including the timeconsuming calculations for the Ephemerides. ${ }^{44}$

\section{Sajnovics and Hell in the whirlwind of enlightened reform}

Ever since Hell and Sajnovics first presented their theories, the response to them has been highly ambivalent in their native environment: mainstream Hungarian scholarship has tended to embrace and improve upon them, while significant academic subcultures fed by proud ethno-national ideology have looked at them with suspicion, dismay and contempt. Here we are only concerned with the immediate contemporary context. Hell and Sajnovics were both vocal patriots of the multi-ethnic Kingdom of Hungary, a composite state that enjoyed historic liberties and a measure of autonomy within a still larger unit, the Habsburg monarchy. This autonomy, however, came to be contested in the very same thrust of Habsburg reforms which at first swept away the Jesuit order, the other cornerstone of Hell's and Sajnovics's identity, and a good decade later evoked protest among the Hungarian elite. These developments threw our protagonists in a vacuum. They were indisputably Hungari, but not recognisable as Magyar: their former association with a cosmopolitan and generally derided religious order and their continued association with a "foreign" court made their allegiances look questionable; and while their dedicated interest in "things Magyar" might have commended them to the leading voices of the incipient movement of national awakening, the combination of the above-mentioned factors with the substance of their findings had a fundamental effect on the way in which their epoch-making discovery was received in the late eighteenth century.

In the Habsburg Monarchy the suppression of the Jesuit order in 1773 was tied up with the efforts of the rulers and their governments towards the administrative consolidation

\footnotetext{
${ }^{44}$ M. Hell, “Observationes astronomicae latitudinum et longitudinum geographicarum," Ephemerides Astronomicae ad Meridianum Vindobonensem Anni 1791 (1790), 301-304.
} 
Per Pippin Aspaas \& László Kontler, "Before and after 1773: Central European Jesuits, the Politics of Language and Discourses of Identity in the Late Eighteenth Century Habsburg Monarchy", final manuscript version ("postprint") of book chapter in Gábor Almási \& Lav Subarić (eds.), Latin at the Crossroads of Identity: The Evolution of Linguistic Nationalism in the Kingdom of Hungary (Leiden: Brill, 2015), pp. 95118. (=Brill's book series Central and Eastern Europe: Regional Perspectives in Global Context, vol. 5)

of their territories. ${ }^{45}$ This agenda hurt many interests. In the Hungarian provinces its pursuit provoked the nobility in a concentrated effort to entrench their ancient privileges, while some of them were to combine this reaction with a vernacular version of enlightened improvement. Simultaneously with the changing climate in Vienna vis-à-vis the Jesuits during the 1760s, the dormant conflict between the court and the Hungarian nobility burst into the open during the Diet (parliament) of 1764-65, as a result of which neither Maria Theresa nor Joseph II ever convoked it again. In this atmosphere, there was an opportunity for a community of interest to rise between the privileged elite of Hungary and the Jesuit order. Yet, in the given case the apparently innocent scholarly investigations of the Demonstratio became flammable ideological material, because they ran counter to the old discourse of historical origin, identity and social exclusiveness professed by the nobility and challenged by the measures urged by Vienna. ${ }^{46}$ At the core of this discourse was, since the high Middle Ages, the idea of a prestigeous steppe kinship of the Hungarians with the mighty Huns, and the proposition that the scions of the (originally) military aristocracy of these conquering "Scythians" enjoy preeminence within the corpus politicum. These convictions were smoothly combined with the traditional classification of the Hungarian language as one of the "oriental" languages. Questioning one pillar of this complex intellectual edifice constituted a challenge to the entire ideological frame and, especially in politically critical times, could expect an appropriate response.

While strictly academic circles tended to welcome Sajnovics's theory in Hungary just as they did more broadly in Europe, there was one important and influential group on the public intellectual scene, among whom many realised the political and ideological stakes of the matter all too well, and reacted accordingly; and it was men of letters of noble origin who

\footnotetext{
${ }^{45}$ W. Müller, "Der Jesuitenorden und die Aufklärung im süddeutsch-österreichischen Raum," in Katholische Aufklärung - Aufklärung im katholischen Deutschland, ed. by H. Klueting with N. Hinske and K. Hengst (Hamburg 1993), 225-245. See also H. Kröll, "Die Auswirkungen der Aufhebung des Jesuitenordens in Wien und Niederösterreich: Ein Beitrag zur Geschichte des Josephinismus in Österreich," Zeitschrift für bayerische Landesgeschichte 34 (1971), 547-617; on the consequences of the suppression to the members of the order, H. Haberzettl, Die Stellung der Exjesuiten in Politik und Kulturleben Österreichs zu Ende des 18. Jahrhunderts (Vienna 1973); A. Trampus, I gesuiti e l'Illuminismo: Politica e religione in Austria e nell'Europa centrale (1773-1798) (Florence 2000).

46 The following paragraphs summarise the argument advanced in Kontler, "Distances Celestial and Terrestrial," 739-750; see also id., "Politicians, Patriots and Plotters: Unlikely Debates Occasioned by Maximilian Hell's Venus Transit Expedition of 1769," in Meeting Venus: A Collection of Papers Presented at the Venus Transit Conference in Troms $\phi$ 2012, ed. by C. Sterken and P. P. Aspaas (Brussels 2013), repr. from The Journal of Astronomical Data 19, no. 1 (2013), 83-93.
} 
Per Pippin Aspaas \& László Kontler, "Before and after 1773: Central European Jesuits, the Politics of Language and Discourses of Identity in the Late Eighteenth Century Habsburg Monarchy", final manuscript version ("postprint") of book chapter in Gábor Almási \& Lav Subarić (eds.), Latin at the Crossroads of Identity: The Evolution of Linguistic Nationalism in the Kingdom of Hungary (Leiden: Brill, 2015), pp. 95118. (=Brill's book series Central and Eastern Europe: Regional Perspectives in Global Context, vol. 5)

dominated that scene before the 1780s and included important figures of the Hungarian Enlightenment and national awakening. Together they expressed the sentiments of a sizeable elite group whose cultural and intellectual horizons, thanks to their education as members of Maria Theresa's famous Hungarian Guards, were broadly European, but whose vision of the future restoration of the erstwhile greatness of the Hungarian nation was predicated on galvanising their own class to a new dynamism through modern letters and knowledge practices. This was a vision of improvement which, in their own view, depended on maintaining a discourse of identity built on a prestigious pedigree and social exclusiveness, both under serious attack from the mid-1760s onward by the Viennese court and government. In this atmosphere, the implications of Finno-Ugrianism-understood by them as not only linguistic but also ethnic kinship — seemed to them highly disturbing. The tone in which they repudiated the theory varied from poetic sarcasm to consternation over the supposed kinship with primitive, "fish-smelly" Lappians, expressed in the discursive frame of the enlightened racism of eighteenth-century philosophical history and ethnographic othering. ${ }^{47}$

To complicate matters still further, while the theory advanced by Sajnovics and embraced by Hell on the origin and nature of the Magyar language met strong rejection among the Hungarian enlightened nobility, Hell soon found himself in the same camp with the detractors vis-à-vis one of Joseph II's important reform initiatives: the language decree of

\footnotetext{
47 Ábrahám Barcsay’s poetry abounds in rebuffs addressed to Sajnovics whose "yoke" was perceived by him a vital threat to ancient liberties, established on the cornerstone of the idea that Hungarians are "the valiant grandsons of Scythians." Similarly, in his "The Errors of Star-Watcher Sajnovits and Hell Being Refuted," Lörinc Orczy casts doubt on the allegation that the progeny of Alexander the Great's brave opponents should be related to mere Lappians munching on dried fish-but recommends "the astronomer" to return to these "kind relatives" of his: a hint at Sajnovics's Slavic ethnic background. In his Magyarországnak törvényes állása (The legal status of Hungary), György Bessenyei wrote that "it is impossible to displace something of such a great consequence, on the basis of so little a circumstance [as language], and set it on a different footing," and suggested that "instead of words, one should consider moral character and manners" (the standard analytical categories of philosophical history). This lens shows the "Scythian" and the "Lappon" to be separated by a yawning gap, and the latter becomes the target of consistent "othering" by Bessenyei. In contrast to the people of Attila, marked by "its thirst for triumph, valour and glory, as well as its sagacity required for domination," the "Lappon" was deformed in his outward appearance as well as his manners: on top of his "ugliness of form, the Lappon is vile and fearful, it is such a subterranean mole of a Nation, which loathes the fight, and never wages war." Gy. Bessenyei, Bessenyei György összes müvei. Prózai munkák, 1802-1804 [The complete works of György Bessenyei: Prose works], ed. Gy. Kókay (Budapest 1986), 231-235. The passage is almost a literal translation from the national characters in Dom Joseph Vaissete's Géographie historique, ecclésiastique et civile, ou description des toutes les parties du Globe terrestre (Paris 1755). For more details, see Kontler, "Distances Celestial and Terrestrial," 744 ff.; see also id., "Politicians, Patriots and Plotters," $87 \mathrm{ff}$.
} 
Per Pippin Aspaas \& László Kontler, "Before and after 1773: Central European Jesuits, the Politics of Language and Discourses of Identity in the Late Eighteenth Century Habsburg Monarchy", final manuscript version ("postprint") of book chapter in Gábor Almási \& Lav Subarić (eds.), Latin at the Crossroads of Identity: The Evolution of Linguistic Nationalism in the Kingdom of Hungary (Leiden: Brill, 2015), pp. 95118. (=Brill's book series Central and Eastern Europe: Regional Perspectives in Global Context, vol. 5)

26 April 1784, which ordered the replacement of German for Latin as the official language of Hungary. ${ }^{48}$

The language decree has been described as a turning point in the relationship of Hungary and the ruler: while earlier measures concerned only partial interests or those of the politically sensitive (such as the abolition of religious orders in the one case, and the removal of the Hungarian crown, the symbol of the country's integrity, to Vienna, in the other), this time the very crassness of the initiative triggered a new awareness of the issue of vernacular language in a much wider circle. Though the emperor made it clear that the decree was not intended to force his subjects to abandon their mother tongue, and only required those who dealt with public affairs to exchange German for Latin, the genie was released from the bottle. While many of the responses from individual counties and municipalities across Hungary seem to have promoted Magyar, the official position of the counties was in favour of the retention of Latin. ${ }^{49}$ Partly, the men of learning who had formulated the responses pointed to cultural and linguistic tolerance in imperial settings from the ancient Persian king Xerxes to the Mongol conqueror Tamerlane, and partly argued that Latin was still the language of science and international communication - as it were, echoing D'Alembert's observations in the preliminary discourse of the Encyclopédie, where he admitted that the use of Latin is "highly expedient in the works of philosophes; its clarity and precision are of great benefit to those who stand in need of a universal language." 50

The full-scale promotion of German as represented by the language decree had, in fact, been preceded by its favouring in more confined but highly important areas, such as elementary and higher level education during the 1770s and the early 1780s. Hell was among those who did not hide their resentment. In scientific publishing, he advocated the use of Latin, or alternatively French, in case Latin was to be dropped. Other vernaculars were not

\footnotetext{
${ }^{48}$ See H. Balázs, Hungary and the Habsburgs, 205-211, and the introduction by Gábor Almási and Lav Šubarić to this volume.

${ }^{49}$ I. Soós, "II. József nyelvrendelete és a 'hivatalos Magyarország"” [Joseph II's language decree and "official Hungary”], in Tanulmányok a magyar nyelv ügyének 18. századi történetéböl, ed. by F. Bíró (Budapest 2005), 261-301.

50 "Discours préliminaire des éditeurs," Encyclopédie, ou dictionnaire raisonné des sciences, des arts et des métiers Tome Premier, ed. by D. Diderot and J. le Rond d'Alembert (Paris 1751), i-xlv, at xxx. Translation taken from H. Balázs, Hungary and the Habsburgs, 210.
} 
Per Pippin Aspaas \& László Kontler, "Before and after 1773: Central European Jesuits, the Politics of Language and Discourses of Identity in the Late Eighteenth Century Habsburg Monarchy", final manuscript version ("postprint") of book chapter in Gábor Almási \& Lav Subarić (eds.), Latin at the Crossroads of Identity: The Evolution of Linguistic Nationalism in the Kingdom of Hungary (Leiden: Brill, 2015), pp. 95118. (=Brill's book series Central and Eastern Europe: Regional Perspectives in Global Context, vol. 5)

"universal languages," he argued. ${ }^{51}$ Even so, he did go with the flow to a certain extent. In 1775, several extracts from Hell's Ephemerides Astronomicae were included in German translation in the Beyträge zu verschiedenen Wissenschaften von einigen Oesterreichischen Gelehrten (incidentally, the word "Gelehrten" here represented only ex-Jesuits); in 1777, he joined for a while the editorial board of the Wiener Realzeitung, which aimed to disseminate scientific news to a German-speaking audience; and towards the end of his life, he embraced the work of his former pupil, the Breslau professor Anton Jungnitz, who translated nearly all of Hell's articles from the appendices of the Ephemerides Astronomicae and reissued them in German in the early 1790 s. ${ }^{52}$ This promotion of scientific works in the German vernacular stands in contrast to other statements from the ex-Jesuit. For example, in several outspoken letters to the conservative bishop Carolus (Károly) Eszterházy in Eger, Hell laments the implementation of teaching in German at the University of Vienna. Even masses at the university church were now held in German, Hell observes in a letter from 11 November 1791. As a result, young women attended, and flirted overtly with the students. This would not have taken place, Hell argued, if only the masses had been celebrated in Latin as they were in the "good old days" when the religious and scientific life of the university was under the sway of the Jesuits. ${ }^{53}$

All in all, Hell seems to have felt uneasy to have been characterised as "German" or “Austrian." In 1776, two biographical lexicons were issued in Vienna: one by Alexius Horányi, Memoria Hungarorum et provincialium scriptis editis notorum, another, Das gelehrte Österreich, by Ignaz de Luca. While Hell was no doubt proud to be included in both lexicons, in a letter to his colleague in Berlin, Johann III Bernoulli, he was careful to point out that:

My Hungary (for I am myself an Ungarus) has a more sane attitude towards Astronomy, which is held in high esteem among the Ungari. Here in Vienna, a work called Das Gelehrte Österreich, Part I, from

\footnotetext{
${ }^{51}$ Hell's position as recounted in the travelogue of a Danish student who met Hell several times in the year 1778, see Andreas Christian Hviids Europa: Udtog af en Dagbog holden i Aarene 1777-1780 paa en Reise igennem Tyskland, Italien, Frankrige og Holland [The Europe of Andreas Christian Hviid: Extracts of a diary kept during the years 1777-80 while travelling through Germany, Italy, France and Holland], ed. by M. Harbsmeier, C. Mechlenborg and M. Petersen (Copenhagen [2005]), 369; cf. Aspaas, Maximilianus Hell, 154. ${ }^{52}$ Beyträge zur Praktischen Astronomie, in verschiedenen Beobachtungen, Abhandlungen, Methoden aus den astronomischen Ephemeriden der Herrn Abbe' Maximilian Hell, ed. by A. L. Jungnitz, 4 vols. (Breslau and Hirschberg, 1790-93).

${ }^{53}$ Aspaas, Maximilianus Hell, 155.
} 
Per Pippin Aspaas \& László Kontler, "Before and after 1773: Central European Jesuits, the Politics of Language and Discourses of Identity in the Late Eighteenth Century Habsburg Monarchy", final manuscript version ("postprint") of book chapter in Gábor Almási \& Lav Subarić (eds.), Latin at the Crossroads of Identity: The Evolution of Linguistic Nationalism in the Kingdom of Hungary (Leiden: Brill, 2015), pp. 95118. (=Brill's book series Central and Eastern Europe: Regional Perspectives in Global Context, vol. 5)

the letter A to the letter O, providing a survey of learned men that are now living throughout the Austrian hereditary lands and who have acquired fame through their writings, has been published. Part II, from the letter $\mathrm{O}$ to the letter $\mathrm{Z}$, is now in press; among these prominent authors, the Ungari make up the largest proportion, for they count more than a hundred. This demonstrates that Hungary has flourished, and in fact still flourishes, more splendidly than the rest of the hereditary kingdoms with respect to the cultivation of all kinds of sciences. However, among foreigners Hungary's learned men have remained virtually unknown as a result of the lack of scientific correspondence. ${ }^{54}$

Father Hell was apparently anxious to stress, lest his Berlin correspondent should have any doubts, that he was a Hungarus - and proud of it. His clinging to an identity as Hungarus in the aftermath of the suppression of the Society of Jesus may seem bewildering, considering the contested and hardly welcoming reception that his studies on "Magyar origins" had received in Hungary. However, in an atmosphere where his old patrons at the Viennese court had proved themselves capable of deserting their roles as protectors of both the Society of Jesus and the Latin language, Hell's insistence on a Hungarus identity perhaps signalled his allegiance to a Latinate tradition that still persisted in the kingdom of his birth.

Less is known about the sentiments of the other protagonist of our story, János Sajnovics. His letters are not preserved and he certainly kept a low profile in public life after his dreams of becoming the royal astronomer of Hungary had proved unrealistic.

\section{Conclusion}

Prior to 1773, Central European Jesuits like Hell and Sajnovics had good reasons to cultivate an identity based on a complex but apparently coherent set of allegiances, of which we may single out four. Firstly, they adhered to the international republic of letters, with Latin still possessing strong positions in its communication practices. Secondly, they were loyal to the pro-Catholic Habsburg dynasty governing a composite monarchy in which Latin remained an important ingredient. Thirdly, they belonged to the Jesuit order with its commitment to the promotion of learning, and Latin learning in particular. And finally, they were part of the

\footnotetext{
${ }^{54}$ Hell to J. Bernoulli in Berlin, dated Vienna 15 February 1777 (Universitätsbibliothek Basel): "Ungaria tamen mea (nam ipse Ungarus Sum) Saniorem de Astronomia Sensum habet, maximoque apud Ungaros in pretio est. Prodijt hic Viennae, sub titulo: das gelehrte Oesterreich, Pars I. à littera A, ad, O, Virorum doctorum per Regna haereditaria austriaca Scriptis clarorum, nunc inter vivos versantium; Pars II à littera $\mathrm{O}$, ad Z, sub prælo est; celebriores hos inter Scriptores, Ungari maximum efficiunt numerum, centenis enim plures sunt, unde constat, Ungariam prae caeteris Regnis haereditarijs, Scientijs omnis generis excultam maxime floruisse, actuque florere, licet apud Exteros hactenus (defectu commercij litterarij) pene ignoti fuerint Viri docti Ungariae."
} 
Per Pippin Aspaas \& László Kontler, "Before and after 1773: Central European Jesuits, the Politics of Language and Discourses of Identity in the Late Eighteenth Century Habsburg Monarchy", final manuscript version ("postprint") of book chapter in Gábor Almási \& Lav Subarić (eds.), Latin at the Crossroads of Identity: The Evolution of Linguistic Nationalism in the Kingdom of Hungary (Leiden: Brill, 2015), pp. 95118. (=Brill's book series Central and Eastern Europe: Regional Perspectives in Global Context, vol. 5)

multi-ethnic Kingdom of Hungary with its Hungarus, Latinate cultural traditions. The suppression of 1773, part of an overall programme of enlightened administrative reform in the Habsburg Monarchy, signalled the breakdown of this coherence. Our protagonists, especially Hell, vigorously tried to counter this development with a strategy of amplifying the still viable elements of these allegiances, and forging new alliances. While they were kept on the payroll of the Habsburg Monarchy as university professors (Hell in Vienna and Sajnovics in Buda and Pest, where the University of Tyrnavia was moved in 1774 and 1777, respectively), they experienced a loss of ideological support from their rulers. In this situation our two ex-Jesuits appealed both to the international republic of letters, where their scholarly credentials were still strong, and to the Hungarian patria. Hell's publications continued to receive attention and acclaim in Europe's main review journals. In these publications Hell made a special effort to extol the excellence of science cultivated in new centres of learning in the eastern half of the monarchy in Hungarus contexts. ${ }^{55}$ It might seem paradoxical that these efforts failed to receive universal acclaim from Hungarian intellectuals. However, counter to Hell's promotion of Hungarian excellence in science stood his and Sajnovics's works on Hungarian ethnohistory, in which they had discarded the proud Scythian ancestry of the Magyars and embraced the controversial Finno-Ugrian theory. In the political-ideological climate of the 1770 s and 1780 s, to a substantial segment of opinion-makers the claims and credentials of Hell and Sajnovics as Hungarian patriots were unacceptable, even hilarious and outrageous. As salaried state servants, Hell and fellow ex-Jesuits managed to retain safe, even respectable positions. But however much he was able to ingratiate himself with and receive some patronage from weighty magnate-prelates, his dream of refashioning Hungary as the torchbearer of Catholic learning in Habsburg Central Europe ${ }^{56}$ — with himself as its main champion-became thwarted because of the alienating effect exerted on an influential elite group by the position he and Sajnovics occupied on the issue of the Hungarian language. The hostility thus generated could not even be set off by the potentially common ground between them and Hungarian patriots vis-à-vis the imperial promotion of German against both Latin and the local vernaculars.

\footnotetext{
55 Aspaas, Maximilianus Hell, 151-155; Kontler, "The Uses of Knowledge."

${ }^{56}$ Kontler, "The Uses of Knowledge."
} 
Per Pippin Aspaas \& László Kontler, "Before and after 1773: Central European Jesuits, the Politics of Language and Discourses of Identity in the Late Eighteenth Century Habsburg Monarchy", final manuscript version ("postprint") of book chapter in Gábor Almási \& Lav Subarić (eds.), Latin at the Crossroads of Identity: The Evolution of Linguistic Nationalism in the Kingdom of Hungary (Leiden: Brill, 2015), pp. 95118. (=Brill's book series Central and Eastern Europe: Regional Perspectives in Global Context, vol. 5)

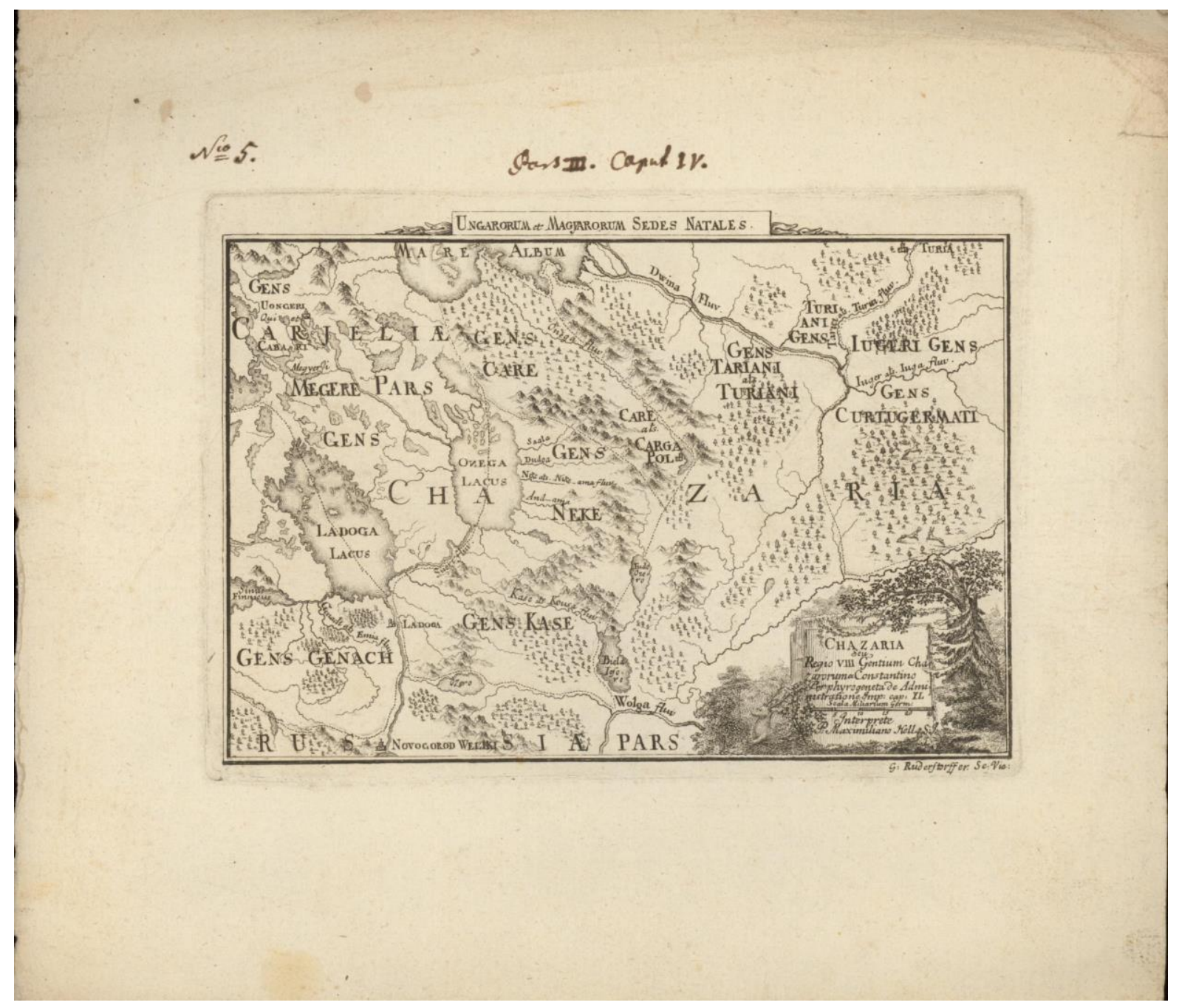

Figure Maximilian Hell, Map of Karelia, the original homeland of Hungarians. COURTESY OF UNIVERSITÄT WIEN, INSTITUT FÜR ASTROPHYSIK. 